\title{
Public Concession Models and Project Efficiency: Do Private Firms Hidden Interest Count?
}

\author{
Paul Ojeaga \\ Federal University of Agriculture Abeokuta, Nigeria.
}

\begin{abstract}
The study provides some facts on the Private Finance Initiative in Nigeria. Public Concession is becoming quite popular in Nigeria with Lagos State of Nigeria trying to implement the model in its infrastructural delivery process. However the model continues to meet with stiff resistances instances of clashes of interest between the principal and agents which are known to run in counter directions. Cost Implicative factors, lack of transparency and other budget constraints affect the delivery process all of these are all briefly addressed in this study.. Despite this it was found that PPP continues to drive increases in the efficiency of project delivery in Nigeria, suggesting that the process should be encouraged and sustained.
\end{abstract}

KEYWORDS: Entrepreneurial Activity, Public Concession, Public Private Participation and Nigeria

\subsection{INTRODUCTION}

This section introduces the study and gives some background information on the subject matter. The Nigeria- public procurement- scheme -till date has not received adequate attention and scrutiny from researches utilizing data to investigate the efficiency of the scheme in Nigeria generally.

Quantitative data can provide some insight on the significance of the Nigerian government's -Public Private Partnership- (PPP) scheme on project delivery with data specifically on direct credit to the private sector finding good use as a measure for PPP and study its impact on the Nigeria social goal delivery programme.

-Agents- (i.e. private firms in the public -procurement- and -project execution process- of -public infrastructure delivery-) often have peculiar hidden characteristics that can affect project outcome in general in cases were sufficient incentives are not given. Private firms are self-maximizing therefore in an attempt to engage the private sector in the public infrastructural delivery process, an in-depth understanding of the mode of engagement with such private agencies will be of strong concern to the public works department as well as government.

Olurinola, Alege, Ojeaga, and Oluwatimiro, Q. (2014) state that Welfare maximization remains the greatest challenge that any democratic government has to face, In an attempt to deliver public goods, therefore there exist huge capital constraints that forces public agencies to search for reasonably efficient methods to do so through the engagement of the private sector.

-Public-Private-Partnership is a mechanism or model used for achieving a social choice function. It therefore provides a foundational model for the public procurement programme by considering private and public sectors inter-relationship in delivering social services (public goods). The PPP is a joint effort between the public and private sector, for the efficient management of scarce resources and the subsequent delivery of public goods in a timely manner. The process of the structure of the relationship of the public principal and the private agents are often studied under the mechanism design paradigm. Mechanism design 
is multi party reverse game with players of divergent interest who collaborate together to realize a project of social outcome Olurinola, Alege, Ojeaga, and Oluwatimiro, Q. (2014).

The PPP process became very popular in the early 1980s under the Thatcher administration, however according to Lambert and Lasley (2006) the actual date of its inception remains unknown. Evidence from World Bank Statistics 2011 show, that the PPP process was utilized in projects in much earlier times as far back as the 1940s. The United Nations 2011 Report also shows that Nigeria will need to invest heavily to prevent further decadence in its dilapidating infrastructural sector. With as much as 15.9 to 17 billion dollars needed over the next decade to maintain a fairly robust infrastructural delivering scheme for the country by the year 2020 .

Past studies state that Nigeria only invests about $5 \%$ of its yearly GDP on infrastructural projects spending an average of 90 billion dollars on consumption alone which is not sustainable in the long run. Due to high consumption spending largely concentrated on food related imports, household consumables, electronics and automobiles, the Nigerian budget financing process remains highly volatile and not likely to meet the needed infrastructural requirements in the near future. The Nigeria import bill continue to mount a heavy burden on trade balance and fiscal concerns, with continue decline in the nation's foreign reserves since the year 2013 see Olurinola, Ojeaga, Alege and Oluwatimiro (2014).

The study concentrates on investigating the effect of the PPP process on project efficiency in Nigeria, data for 52 years is obtained from the data market of Iceland, which also archives World Bank data and other relevant data sources. The method of estimated as stated earlier is the linear mixed effect regression. It is maximum likelihood model that is based on the premise that the sample distribution will converge to that of the population. It robustness stems from it efficiency and asymptotic properties that make the technique attractive for fairly accurate results for inference purposes.

Mechanism design is a reverse game theory design that studies the interaction between multiple players in the social delivery system. Where the mechanism is designed using game theory and the outcome of the game is known by an entity called the principal (where the principal in this case could be government or its public agencies) who initiates the process in the presence of specific incentive for the agents (who in this case could be firms or individuals) in order to realize the fundamental goals.

It is often referred to as the best delivering mechanism for countries with huge social needs (i.e. need for the provision of basic socio economic infrastructure) but are plagued with limited budgetary allocation to do so. Social welfare that is to be provided is often termed needs. Needs in this case will made to refer to the welfare needs of the general public that needs to be maximized, these may include roads, bridges, hospitals, national parks, town halls, schools, provision of electricity, water supply etc. It is often the set of programmes that a government is often elected to power to achieve within a given specified period of time. In this study infrastructure availability as a percentage of the population is utilized.

The project awardee and originator is often referred to as the principal. This is often the public awarding institution or government of the project or task to be achieved, who may want to utilize the private sector in realizing its welfare provision mechanism. It may want to rely on the private sector to realize its projects for the following reasons. It might be a more efficient way of realizing the task, secondly there might be budgetary conditions that it might want to circumvent, and there might also be concerns of managing the project after completion and probably the need to get back return on such investment through an effective public tax scheme in the use of the institutional facility provided.

The principal also has full information on the project type but does not have full information on the agent allowing the principal to result to incentive schemes to make the agent behave appropriate since the principal is risk averse and the agent is likely to exhibit a moral hazard behavior if not regulated.Agents can be described as collaborative firm and individuals who work with the principal or the public agency with the intent to deliver the goals of the principal which is often the task to be realized. They could also include multinational organizations or enterprises that operate within a country and are willing to help provide public services which they also benefit from after going through a rigorous operational understanding with the government and people of the host country. 
The memorandum of understanding MOU is the terms and conditions for agreeing to work together.It is usually signed by the parties involved in the project. In the case of the study it could be between the principal or principals and the agent or agents involved. The quality of the MOU can also affect the outcome of the project, the quality of the project as well as the future maintenance of the facility including its ownership structure and the conditions of revenue allocation and derivation from the running and operation of the project. Public Private Partnership (PPP), this is collaboration between the public and private sector in realization of the public infrastructural delivery process in a country. The earliest form of the PPP in Nigeria dates back to as far as the 1930s, although data for the study is only available from 1960 as at the time of independence till date. The measure of PPP utilized in this study is direct capital to private sector firms. The reason for this is that if firms, access of capital are on the increase therefore their ability to partner with government is likely to be more frequent owing to the availability of funds at their disposal.

SOME PPP MODELS: There exist various PPP models; these models are quite popular in industrial economics, industrial engineering and in architecture and civil engineering. For the sake of brevity and specificity this study will consider, three major PPP model for the sake of this research: they include, the Build Operate Own (BOO), the Build Operate Transfer (BOT), and the Build Operate Own and Transfer Models.

a.) The Build Operate Own (BOO) Model: This is a model in which the principal has an understanding with the agent(s) to deliver a project or task, operate it for a given or specified period of time and own it at the end of the agreed time. The reason for operation could be that the principal will have incurred cost that it finds it reasonable that the agent operates the facility with the intent of the principal recovering the cost of building the facility in the period under which the facility is under the operation of the agent who may charge the general public a token fee for the public usage of the facility in this period the principal will have recovered its money from the agent operation of the facility allowing the agent to own the facility subject to specified conditions of public operations.

b.) The Build Operate Transfer (BOT) Model: The build operate transfer model is a model in which the principal has an understanding with the agent(s) to deliver a project or task, operate it for a given or specified period of time and transfer it to the principal at the end of the agreed time. The reason for operation could be that the principal will have incurred cost that it finds it reasonable that the agent operates the facility with the intent of offsetting the cost of building in the period under which the facility is under the operation of the agent who may charge the general public a token fee for the public usage of the facility.

c.) Build Operate Own and Transfer (BOOT) Model: This is the build operate own and transfer Model. In this model the principal usually, allows the agent to own operate the facility, so that it can recover the cost of building the facility, after which it might require that the agent own the facility for a concession fee for a specified period of time. On the expiry of the time of ownership the agent might need to bid for the facility to own for another specified period of time after which the facility is transferred once again to the principal.

d.) Project Efficiency: Time to complete contract is the measure of project efficiency utilized in the study. This in turn is a subject of institutional factors such as the time processes, for a review of a contract since a contract review committee is likely to sit to consider the new budget adjustment for a project.

e.) Delivery Cost: This is the cost of delivering a project in a country. This can affect the delivering process in a case where the business environment is risky and volatile. It often depicts the level of inflation in the country which could affect the budgeting process of the project and the cost of acquiring specific machinery for the completion of the task or project. This (i.e. delivery cost) is many a time hampered in a country like Nigeria by inflation, where such a factor as this, can lead 
to a case of re-evaluation of the budget, leading to the possible delay and the increase in cost of the project.

This study examines the link between agent's hidden interest and project efficiency and cost for Nigeria by designing an optimal cost delivery model for Nigeria. It employs the use of game theory to develop the model specification to be implemented in the study. A connection is established on how Public Private Participation Paradigm can affect project efficiency in Nigeria, by investigating the practical implementation of the theory of mechanism design as proposed by Maskin, Hurwicz and Myerson (2007).

The emphasis of the study is on the implicative effect of different PPP models on project efficiency in Nigeria. It also describes the implicative effect of different PPP models which includes the Build Operate transfer, Build Operate Own and the Build Operate Own Transfer Models on Project efficiency for Nigeria. It also attempts to fit data for Nigeria from 1960 to 2013 using Public Finance Initiative (PFI) data and other proxies for different variables identified to be relevant for the PPP process. The study also provides new further insight into the likely modus operandi for realizing a successful PPP process for Nigeria. The research questions investigated in the study include:

i) To examine if Public Private Partnership can promote project efficiency in Nigeria?

ii) To ascertain if Public Private Partnerships Memorandum of Understanding (MOU) has a significant effect on project efficiency in Nigeria.

iii) $\quad$ iii) To determine if budget constraint has a significant effect on project efficiency in Nigeria?

\subsection{DATA, THEORY AND METHODOLOGY}

\subsection{DATA}

In this section the data used in the study is presented see Table 1. All data for Nigeria were obtained from the World Development Indicator of the World Bank for the period of 1960 to 2010 a period of 52 years and are previously utilized in the study by Olurinola, Ojeaga, Alege and Oluwatimiro (2014). PPP in this case is the aggregate domestic credit provided to the private sector as a percentage of GDP, budget constraint is also 
Table-1: Description of All Variables Used in the Study

\begin{tabular}{|c|c|c|c|}
\hline Variables & Sources & $\begin{array}{l}\text { Abbreviation } \\
\mathrm{S}\end{array}$ & Description \\
\hline Public Privates Partnerships & World Bank Data & PPP & $\begin{array}{l}\text { The total domestic credit in USD } \\
\text { provided to the private sector as a } \\
\text { percentage of GDP }\end{array}$ \\
\hline Infrastructure/Capita & World Bank Data & Needs & $\begin{array}{l}\text { The total road length in kilometers in } \\
\text { Nigeria as a percentage of population }\end{array}$ \\
\hline Budget Constraint & World Bank Data & $\mathrm{BC}$ & $\begin{array}{l}\text { The total claims on government as a } \\
\text { percentage of GDP }\end{array}$ \\
\hline Private Participation & World Bank Data & PP & $\begin{array}{l}\text { The total private capital outflow as a } \\
\text { percentage of GDP }\end{array}$ \\
\hline Private Sector Interest & World Bank Data & PSI & $\begin{array}{l}\text { The total private sector net outflow in } \\
\text { constant USD }\end{array}$ \\
\hline Government Interest & World Bank Data & GI & $\begin{array}{l}\text { The total government spending as a } \\
\text { percentage of GDP over time }\end{array}$ \\
\hline Memorandum of Understanding & World Bank Data & MOU & $\begin{array}{l}\text { The percentage private to public sector } \\
\text { interest in project executed overtime } \\
\text { measured using private sector outflow } \\
\text { over government spending overtime. }\end{array}$ \\
\hline Liquidity to Liability Ratio & World Bank Data & LLR & $\begin{array}{l}\text { This is government liquidity to liability } \\
\text { ratio }\end{array}$ \\
\hline Delivery Cost & World Bank Data & DEC & PPP delivery cost (PPP times inflation). \\
\hline Project Delivery & World Bank Data & PRJ & $\begin{array}{l}\text { This is country specific budgetary } \\
\text { allocation times possible constraints to } \\
\text { project delivery such inflation. }\end{array}$ \\
\hline Project Efficiency & World Bank Data & $\mathrm{EFF}$ & $\begin{array}{l}\text { These are institutional measures which } \\
\text { account for regulated contracts and } \\
\text { oversight of the contract award, } \\
\text { supervision and quality assurance } \\
\text { standards }\end{array}$ \\
\hline Foreign Investment in PPP & World Bank Data & FORIN & $\begin{array}{l}\text { The total foreign Investment inflow as } \\
\text { a percentage of GDP }\end{array}$ \\
\hline
\end{tabular}

Note: All data are obtained from the data market of Iceland.

the total claims on government as a percentage of the gross domestic product (GDP), and project efficiency is captured using institutional measures such as contract regulation and award procedures, contract oversight, supervision and finally quality assurance. The PPP process is captured using direct credit flows to the private sector since most private agents are private firms. The memorandum of understanding (MOU) is captured using percentage private sector to public sector participation and in this case the ratio of private sector outflow to direct credit inflow to the private sector, lastly the delivery cost is measured using cost of all project overtime with inflation accounted for during the lifespan of the project, captured using PPP cost multiplied by inflation overtime as a proxy measure. Three other variable sare generated for the study they include build operate transfer (here PPP is interacted with private sector participation variable), build operate own (here PPP is interacted with private sector interest)and the build operate own and transfer(here PPP is private sector interest and private sector participation). These allows for capturing firms hidden interest in the regulated contracts arising from specific PPP models for project implementation. 


\subsection{THEORY AND METHODOLOGY}

Two major design problems that past scholars identify to be associated with mechanism design include the goal often associated with the design and the mechanism for achieving this goal which is often unknown.

The basic properties of mechanism design games include that the game designer determines the structure of the game, and therefore does not inherit one and this designer only has interest in the outcome of the game. It is also a private information game where one of the agents referred to as the principal selects the payoff structure of the game Hurwitz (2004).

Harsanyi (1967) and Hurwitz and Reiter (2006) also state that agents within the game structure also receive secret information from the game which often contain relevant payoffs e.g. preferences, quality and cost and the principal derives its utility from these.

Hurwitz and Reiter (2006) provide strong in-depth information on game time (in this case relevant to project time) stating that mechanism design often follow specific patterns which include that the principal commits to a mechanism with an outcome $\mathrm{Y}$, and that agent will report their type in this case their possible dishonesty or any other type of portfolio allowing the mechanism to be executed and agents receive their payoffs at $Y=(\widehat{\theta})$. The utility of the principal is $Y=(\widehat{\theta})$ and is the possible social outcome. Therefore under the aforementioned strategy the the social goal design will have to take into considering the following

i.) The principal will design a system or mechanism that will implement a social choice function $\mathrm{Y}(\theta)$.

ii.) The principal will try to find a value criterion that maximizes the social choice function $\mathrm{Y}(\theta)$ through PPP projects of procurements.

Therefore $f(\theta)=x(\hat{\theta}(\theta))$ can be defined as the social choice function, while stating that $f(\theta)$ is the social choice function and $t(\theta)$ is the transfer function which is equal to $x(\theta)$ which in this case is the project outcome that the principal induces the agent to pick through some form of motivation or other forms of payoffs due to a specified transfer function. $\widehat{\theta}$ will be referred to as the optimal social choice which offers the principal some utility see Hurwitz and Reiter (2006) for detailed explanations.

Further insight into mechanism design problems is provided by Loeb and Magat (1979) to examine cases of regulated contracts where there exist no social costs of leaving rent to agents thereby ignoring the social cost of public funds in their model, they state explicitly that it is necessary to award agents the whole net consumer surplus to a good investment.

Cases of regulated contracts are also studied by Sappington (1980). Sappington introduces the social cost of public funds which were neglected in previous study by Loeb and Magat (1979) stating that costs have implicative effects on the principal and agents commitment to contracts.

The adverse selection problem is also investigates by Myerson (1982), who intensively argues that when an agent cannot be observed the social optimal price an agent is allowed to charge often exceeds its Ramsey levels.

Reputation models are also extensively presented by Lewis (1986), Hart and Holmstrom (1987) and Laffont and Tirole (1989) who state that the extent of under-investment and cost overruns are asserted to be a function of length and the relationship between the principal and agents and state that while relationships might be a condition for the guarantee of appropriate investment issues of cost overruns such as changes in technology do not affect do not cause agency problems since they result to upgrading or downgrading cost simplification of projects in general. 
The study by Chiang (2002) on moral hazard problem also show that moral hazard problems were found to decrease by the power of incentive $n$-fold when the number of principal increases from 1 to $n$ for a risk adverse agent.

Laffont and Tirole (1993) also states that the adverse selection and moral hazard problem under a single model in a social optimal contract case makes the agent to invest in an efficient manner and to obtain positive rent which otherwise in an inefficient case gives the opposite outcome.

Tsai (2007) examines the mechanism design literature further and states that linear payoff contract where there is a fixed payoff and performance- based payoff component could be replicated using two incentive schemes price cap and cost of services in regulated contracts. Finally the study by Mathios and Rogers (1989) investigated the effect of price cap and cost of services on average intra state telephone rates and find in states where price caps were adopted lower rates were charged for cost of service delivery

The theory and methodology utilized in the study are briefly explained. project delivery (prjdel) is likely to depend on availability of funds (bc) for project execution, the delivery cost (dec) for the project and the social choice function ((sc) i.e. the public need to be maximized). Therefore it can be stated that how efficiently executed project is can be expressed as

$$
\text { prjdel }=\text { bc }+ \text { dec }+ \text { sc........... (1) }
$$

while the cost of delivery will be a function of the cost of signing the ppp memorandum of understanding (mou), the ppp model utilized and the public need (sc) to be maximized. this is likely to be true since the memorandum of understanding cost such as legal cost and other cost evaluations such as the bill of quantities summary for carrying out the project will be cost into the delivery cost of the project.

$\mathbf{d e c}=\mathbf{m o u}+\mathbf{p p p}+\mathbf{s c}$.

Government (the principal that is concern with social needs provision), interests will be guided by their electoral promises to the electorate which will inform the social choice (sc) as well as the implicative cost of renting seeking interests (rs) of government officials in the public or civil service since such public concession processes will have to pass through government evaluation processes termed due processes. $\mathrm{i}$ will therefore proceed to express government interest as follows

$$
\text { gi }=\mathbf{s c}+\mathbf{r s} \ldots \ldots \ldots \ldots \ldots \ldots . . . . . .(3)
$$

Normal form games provide strong intuition regarding the behavior of the principal and the agent in the outcome of the social choice function presented below in tables 2 to 4 are the resultant payoffs associated with principal and agent behavior at different scenarios in the contractual stages of a project. 
Table 2: Budget Constraint, Project Efficiency and PPP models with no incentives

\begin{tabular}{|l|l|l|}
\hline Strategy & $\begin{array}{l}\text { State 1 ntate 2 } \\
\text { Principal does not } \\
\text { engage }\end{array}$ & Principal engages \\
\hline $\begin{array}{l}\text { High Cost Project With } \\
\text { low ROI }\end{array}$ & $\begin{array}{l}\text { Project not embarked on } \\
\text { Project embarked on } \\
\text { without Private sector } \\
\text { input }\end{array}$ \\
\hline $\begin{array}{l}\text { Condition B } \\
\text { High ROI }\end{array}$ & $\begin{array}{l}(1,0) \\
\text { Project Project With } \\
\text { input public sector }\end{array}$ & $\begin{array}{l}\text { Project embarked on by } \\
\text { both Private public } \\
\text { sector input }\end{array}$ \\
\hline
\end{tabular}

Note: The above show the strategies for delivering public welfare with or without the principal and the agent inputs and the payoff depicts the utility of the public given the social outcome delivery model. Some measure of utility is attainable in condition A and condition B state 2 .

Table 3 Budget Constraint, Project Efficiency and PPP models with minimal Incentives

\begin{tabular}{|l|l|l|}
\hline Strategy & State 1 ntate 2 \\
Principal does not & Principal engages \\
engage & $(0,0)$ & $(2,0)$ \\
\hline $\begin{array}{l}\text { High Cost Project } \\
\text { With low ROI }\end{array}$ & $\begin{array}{l}\text { Project not embarked } \\
\text { on }\end{array}$ & $\begin{array}{l}\text { Project embarked on } \\
\text { without Private sector } \\
\text { input }\end{array}$ \\
\hline $\begin{array}{l}\text { Condition B Cost Project } \\
\text { With High ROI }\end{array}$ & $\begin{array}{l}\text { Project embarked } \\
\text { without public sector } \\
\text { input }\end{array}$ & $\begin{array}{l}\text { Project embarked on by } \\
\text { both Private public } \\
\text { sector input }\end{array}$ \\
\hline
\end{tabular}

Note: The above show the strategies for delivering public welfare with or without the principal and the agent inputs and the payoff depicts the utility of the public given the social outcome delivery model. Some measure of utility is attainable in condition A and condition B state 2. 
Table 4 Budget Constraint, Project Efficiency and PPP models with reasonable Incentives

\begin{tabular}{|l|l|l|}
\hline Strategy & $\begin{array}{l}\text { State 1 } \\
\text { Principal does not } \\
\text { engage }\end{array}$ & Principal engages \\
\hline $\begin{array}{l}\text { High Cont Project } \\
\text { With low ROI }\end{array}$ & $\begin{array}{l}\text { Project not embarked } \\
\text { on }\end{array}$ & $\begin{array}{l}\text { Project embarked on } \\
\text { without Private sector } \\
\text { input }\end{array}$ \\
\hline $\begin{array}{l}\text { Condition B } \\
\text { With High ROI Project }\end{array}$ & $\begin{array}{l}\text { Project embarked } \\
\text { without public sector } \\
\text { input }\end{array}$ & $\begin{array}{l}\text { Project embarked on by } \\
\text { both Private public } \\
\text { sector input }\end{array}$ \\
\hline
\end{tabular}

Note: The above show the strategies for delivering public welfare with or without the principal and the agent inputs and the payoff depicts the utility of the public given the social outcome delivery model. Some measure of utility is attainable in condition A and condition B state 2.

Table 5 Budget Constraint, Project Efficiency and PPP models with significant Incentives

\begin{tabular}{|l|l|l|}
\hline Strategy & $\begin{array}{l}\text { State 1 } \\
\text { Principal does not } \\
\text { engage }\end{array}$ & \begin{tabular}{l} 
Principal engages \\
\hline Condition A
\end{tabular} \\
$\begin{array}{l}\text { High Cost Project } \\
\text { With low ROI }\end{array}$ & $\begin{array}{l}\text { Project not embarked } \\
\text { on }\end{array}$ & $\begin{array}{l}\text { Project embarked on } \\
\text { without Private sector } \\
\text { input }\end{array}$ \\
\hline $\begin{array}{l}\text { Condition B } \\
\text { High Cost Project } \\
\text { With High ROI }\end{array}$ & $\begin{array}{l}\text { Project embarked } \\
\text { without public sector } \\
\text { input }\end{array}$ & $\begin{array}{l}(4,4) \\
\text { Project embarked on by } \\
\text { both Private public } \\
\text { sector input }\end{array}$ \\
\hline
\end{tabular}

Note: The above show the strategies for delivering public welfare with or without the principal and the agent inputs and the payoff depicts the utility of the public given the social outcome delivery model. Some measure of utility is attainable in condition A and condition B state 2.

In Tables 2 to 5 we consider the public project to be a high cost project as most public projects are known to be in which there is some return on investment (ROI) for the principal, this return could be public goodwill towards an incumbent government due to social services delivered or some form of more internally generated revenue (IGR) for government. The ROI could be high in some cases and low in others allowing for a description of what the decision of the principal and agent will be given each scenario.

The interest is in the condition (condition B) with high return on investment (ROI) and the state (state 2 under condition B) under which the principal and the agent collaborate to deliver a public need. The 
incentive included in the study is to force the agent to behave in a reasonable manner allowing us to understand the conditions under which agents are likely to display their best type. The first table models the general PPP model where the principal and the agent collaborate, with a definition of some form of stake holding underlying ownership interests the second table models the build operate and transfer (BOT) model. The third table models the build operate and own (BOO) model and the fourth table represents the build operate own and transfer model of the PPP process respectively.

In the first case in Table 2, assuming there exist some budget constraint associated with social need provision allowing the maximization problem to be one that is subject to existing financial constraints with no incentives for the agent and if the principal engages it is assumed that the principal will find a willing agent that engages among the pool of bidding firms, under condition $\mathrm{A}$ if the principal fails to engage for a high cost project with low return on investment it is assumed that agents will not engage independently in such projects since they are self-maximizing resulting to the pay-offs in state 1 this is the initial condition Nash Equilibrium.

If the principal engages in condition A state 2 and the project is embarked on without private sector participation it will result to pay-offs for the principal. In Condition B state 1 the project embarked upon with private sector participation alone results in pay-off for the private firms. However under all these conditions, welfare are not maximized at a global optimum even though a local optimum seems to exist which does not appear to be the most efficient. Similar scenarios are also presented in tables 3, 4 and 5 under conditions of minimal, reasonable and significant incentive. Table 4 presents the most efficient optimum. In this case there exist conditions for significant incentive and condition B state 2 offers the global optimum and the most efficient conditions for both the principal and the agent.

The pay-offs from the normal form games above in the Tables above also depict that agents are likely to improve their behavior under conditions where they are likely to benefit substantially. However the optimum condition for project outcome is the condition where there is significant incentive and the principal also regulates the project. Allowing for the argument that the build operate own and transfer model is likely to yield the highest payoffs for both the principal and agent as well maximize social infrastructural or public need provision at a global optimum..

Based on the above argument, a macroeconomic model is presented from the micro foundations of firm's behavior by modeling their aggregate interests and efficiency for Nigeria. the theory therefore presented in the study, is based on a situation in which project efficiency (eff) depends on a host of factors which include: public private partnership (ppp) government budget constraint (bc), social needs (sc), project delivery cost (dec), private participation (pp), private sector interest (psi), government interest (gi), and memorandum of understanding (mou), this is written as:

\section{eff f (PPP bc, sc, dec, pp, psi, gi, mou)}

PPP is now expressed as a decreasing function of six variables which include: social needs( $\operatorname{sc} \leq 0)$, cost of delivery or delivery cost $(\operatorname{dec} \leq 0)$, private sector interest ( $\mathrm{psi} \leq 0)$, government interest $(\mathrm{gi} \leq 0)$, memorandum of understanding (mou $\leq 0$ ), and project efficiency (eff $\leq 0$ ) and an increasing function of budget constraint $(b c \geq 0)$. In other instances different models of ppp are also considered using the same set of explanatory variables they include the bot, boo and the boot these models are expressed below as:

\section{eff f (bot,bc, sc,dec,pp,psi,gi,mou)}

\section{eff f (boo,bc,sc,dec,pp,psi,gi,mou)}

eff f (boot, bc,sc,dec,pp,psi,gi,mou)

The models are estimated using the linear mixed effect optimization estimation (LME). The linear mixed effect estimation method allows us to find relationship between a set of unrelated variables making it quite suitable for the study. The four model specification can be expressed below as: 
(Eqn. 4.) $\mathrm{eff}_{\mathrm{t}}=\propto_{0}+\propto_{1} \mathrm{ppp}_{\mathrm{t}}+\propto_{2} b c_{\mathrm{t}}+\propto_{\mathrm{a}} s c_{\mathrm{t}}+\propto_{4} \mathrm{dec}_{\mathrm{t}}+\propto_{5} \mathrm{pp}_{\mathrm{t}}+\propto_{6} \mathrm{psi}_{\mathrm{t}}+\propto_{7} \mathrm{gi}_{\mathrm{t}}+\propto_{\mathrm{g}} \mathrm{mou}_{\mathrm{t}}+\epsilon_{\mathrm{t}}$

(Eqn. 5.) $\left(\mathrm{eff}_{\mathrm{t}}=\propto_{0}+\propto_{1}\right.$ bot $_{\mathrm{t}}+\propto_{2} \mathrm{bc}_{\mathrm{t}}+\propto_{\mathrm{a}} \mathrm{sc}_{\mathrm{t}}+\propto_{4} \mathrm{dec}_{\mathrm{t}}+\propto_{5} \mathrm{pp}_{\mathrm{t}}+\propto_{6} \mathrm{psi}_{\mathrm{t}}+\propto_{7} \mathrm{gi}_{\mathrm{t}}+\propto_{\mathrm{g}} \mathrm{mou}_{\mathrm{t}}+\epsilon_{\mathrm{t}}$

(Eqn. 6.) eff $_{\mathrm{t}}=\propto_{0}+\propto_{1} \mathrm{boo}_{\mathrm{t}}+\propto_{2} \mathrm{bc}_{\mathrm{t}}+\propto_{\mathrm{a}} \mathrm{sc}_{\mathrm{t}}+\propto_{4} \mathrm{dec}_{\mathrm{t}}+\propto_{5} \mathrm{pp}_{\mathrm{t}}+\propto_{6} \mathrm{psi}_{\mathrm{t}}+\propto_{7} \mathrm{gi}_{\mathrm{t}}+\propto_{\mathrm{g}} \mathrm{mou}_{\mathrm{t}}+\epsilon_{\mathrm{t}}$

(Eqn. 7.) $\mathrm{eff}_{\mathrm{t}}=\propto_{0}+\propto_{1} \mathrm{boot}_{\mathrm{t}}+\propto_{2} \mathrm{bc}_{\mathrm{t}}+\propto_{\mathrm{g}} \mathrm{sc}_{\mathrm{t}}+\propto_{4} \mathrm{dec}_{\mathrm{t}}+\propto_{5} \mathrm{pp}_{\mathrm{t}}+\propto_{6} \mathrm{psi}_{\mathrm{t}}+\propto_{7} \mathrm{gi}_{\mathrm{t}}+\propto_{\mathrm{g}} \mathrm{mou}_{\mathrm{t}}+\epsilon_{\mathrm{t}}$

It is believed that the model is therefore not miss-specified since it takes the first difference of all explanatory variables and asserts that project efficiency depends on list of exogenous variables stated, from past periods since it is not expected that immediate factors will affect the dependent variable therefore accounting for multi-co linearity and autocorrelation in variables.This is done however for just one lag. To account for annual changes in government concession regulations and contract bidding process that might affect project efficiency in years' time fixed effects are incorporated in the model. Other studies that control for time effects include Ojeaga (2017), Ojeaga (2015), Alege, George, Ojeaga and Oluwatimiro (2015) and Ojeaga (2014) and Ojeaga (2013).

\subsection{PRESENTATION OF RESULTS}

The results of the study are presented in Table 6. PPP appear to have a significant effect on project efficiency in Nigeria see Table 6 Column 1. Other models of PPP which include the Build Operate Own and the Build Operate Own Transfer were also having positive significant effect on project efficiency see Table 6 Columns 2 and 4.Budget Constraint also had a negative significant effect on project efficiency in all the for model specifications.

Private firm's interests were also found to have a negative effect on project efficiency. The effect of memorandum of understanding on project efficiency, were mixed and revealing for the different model specifications. The memorandum of understanding was found to matter for the BOT AND BOOT model specification. Depicting that incentive given to private firms could mean that firms are likely to execute project more efficiently. Therefore agents are likely to behave better under conditions of reasonable and significant incentive, in the PPP process. 
Table-6 Regression of PPP on Project Efficiency

\begin{tabular}{|c|c|c|c|c|}
\hline Variables & $\begin{array}{l}(1) \\
\text { LME } \\
\text { Project } \\
\text { efficiency }\end{array}$ & $\begin{array}{l}(2) \\
\text { LME } \\
\text { Project } \\
\text { efficiency }\end{array}$ & $\begin{array}{l}(3) \\
\text { LME } \\
\text { Project } \\
\text { efficiency }\end{array}$ & $\begin{array}{l}(4) \\
\text { LME } \\
\text { Project } \\
\text { efficiency }\end{array}$ \\
\hline Social Needs & $\begin{array}{l}0.001 \\
(0.001)\end{array}$ & $\begin{array}{l}-0.001 \\
(0.001)\end{array}$ & $\begin{array}{l}0.0003 \\
(0.001)\end{array}$ & $\begin{array}{l}0.0004 \\
(0.002)\end{array}$ \\
\hline Public Private Partnership & $\begin{array}{l}0.005^{* * * *} \\
(0.001)\end{array}$ & & & \\
\hline Build Operate Own Model & & $\begin{array}{l}0.001 * * * \\
(0.0002)\end{array}$ & & \\
\hline Build Operate Transfer Model & & & $\begin{array}{l}-0.01 \\
(0.01)\end{array}$ & \\
\hline $\begin{array}{l}\text { Build Operate Own Transfer } \\
\text { Model }\end{array}$ & & & & $48.53 * *$ \\
\hline Budget Constraint & $\begin{array}{l}-0.01 * * * \\
(0.001)\end{array}$ & $\begin{array}{l}-0.01 * * * \\
(0.001)\end{array}$ & $\begin{array}{l}-0.01 * * * \\
(0.003)\end{array}$ & $\begin{array}{l}(21.38) \\
-0.01 * * \\
(0.003)\end{array}$ \\
\hline Interest of the Private Sector & $\begin{array}{l}-0.02 * * * \\
(0.004)\end{array}$ & $\begin{array}{l}-0.06 * * * \\
(0.01)\end{array}$ & $\begin{array}{l}-0.03 * * * \\
(0.01)\end{array}$ & $\begin{array}{l}-0.03 * * \\
(0.01)\end{array}$ \\
\hline Memorandum of Understanding & $\begin{array}{l}0.04 * * * \\
(0.01)\end{array}$ & $\begin{array}{l}0.0139 \\
(0.01)\end{array}$ & $\begin{array}{l}0.0333^{*} \\
(0.0168)\end{array}$ & $\begin{array}{l}0.0258 \\
(0.0235)\end{array}$ \\
\hline Project Delivery Cost & $\begin{array}{l}0.002 * * * \\
(0.0003)\end{array}$ & $\begin{array}{l}0.003 * * * \\
(0.0004)\end{array}$ & $\begin{array}{l}0.002 * * * \\
(0.001)\end{array}$ & $\begin{array}{l}0.002 * * * \\
(0.001)\end{array}$ \\
\hline Government Interest & $\begin{array}{l}7.37 * * * \\
(0.01)\end{array}$ & $\begin{array}{l}6.05^{* * *} \\
(0.01)\end{array}$ & $\begin{array}{l}0.23^{*} \\
(0.01)\end{array}$ & $\begin{array}{l}7.06^{* * *} \\
(0.01)\end{array}$ \\
\hline Time Fixed Effect & Yes & No & No & No \\
\hline Observations & 48 & 48 & 48 & 48 \\
\hline
\end{tabular}

Source: Authors Compilations using State 13. Note: All standard errors are expressed in parentheses. The $\mathrm{p}$ values $* * * \mathrm{p}<0.01, * * \mathrm{p}<0.05, * \mathrm{p}<0.1$.represent $1 \%, 5 \%$ and $10 \%$ significant levels respectively and LME represents linear mixed effects maximum likelihood estimation.

\subsection{DISCUSSION OF RESULTS}

The results present meaningful insight into the relationship between PPP and project efficiency in Nigeria. It was found that PPP was improving the efficient execution of projects across the country adding value to the infrastructural delivery process as well as helping to, maximize public utility see Table 6 Column 1 . It was also found that the $\mathrm{BOO}$ and the BOOT were probably more useful models for improving project delivery in Nigeria See Table 6 Columns 2 and 4. The BOT model had no significant effect on project efficiency see Table 6 Column 2, this can be explained by stating that agents interest often interfere with project outcome were there exist no significant incentive in the public project resulting to a lower level of efficiency. And finally the memorandum of understanding was found to matter for the BOO and BOOT model specifications see Table 6 Column 2 and 4, depicting that a design mechanism where the interest of the private firm is considered is likely to provide useful results in improving service delivery. Budget constraint was also having a negative effect on project efficiency see Table 6. Agents are not likely to perform at optimum in projects where they do not have specific stake holding interest meaning that stake holding interest were a pre-requisite for good agent behavior. The implication of this result is that agents are likely to exhibit a hidden behavior that will lead to moral hazard if left to participate in a project with little or no private benefit to them. Thereby forcing the principal, to result to, incentive giving, in trying to prevent agents, from exhibiting this likely hidden behavior. 


\subsection{CONCLUSION AND RECOMMENDATION}

This section concludes the study and states some recommendations. In concluding the research question of the study are answered. The questions asked included i) If Public Private Partnership can promote project efficiency in Nigeria? ii) If Public Private Partnerships Memorandum of Understanding (MOU) has a significant effect on project efficiency in Nigeria. iii) And finally, if budget constraint has a significant effect on project efficiency in Nigeria? It was found that PPP was promoting project efficiency in Nigeria. It was also found that the nature of the memorandum of understanding was found to matter for PPP models were the private agents have ownership of the facility making them stakeholders in the facility. The build operate own and transfer model appeared to have the highest effect on project efficiency in Nigeria. Finally it was found that budget constraint was having a negative effect on project efficiency.

The result learnt from this study is that agents (i.e. firms) particularly construction firms are likely to continue to exhibit hidden negative behavior as long as they do not have stake holding interest in public projects in Nigeria. PPP particularly the BOO and the BOOT models are probably a way to go in trying to improve the Nigerian public service delivery process. Since this will provide optimum public outcome that is desired in the country, therefore the hidden interest of private agent does count in these models of the public concession process.

The implication of this for stakeholders in the infrastructural sector of the Nigerian economy is that the PPP process in Nigeria should be strengthened through allowing for more transparency in the bidding and concession process and reasonable incentives should be incorporated in the contract allocating process to agents participating in the partnership, in order to strengthen their commitment to projects. It is recommended that policy makers should limit projects as much as possible to a design were the private firm interest are ensured with the intent of improving the utility of the public through the delivery of service to the general public in an efficient manner with the public sector acting as a regulatory body which should ensure that ethics and best practices are met, particularly in the case of the build operate own and transfer model which seems to be most useful in the public project delivery process.

\section{REFERENCES}

[1] Afolabi (2011). The Impact of Oil Export on Economic Growth in Nigeria from 1970 -2006

[2] Baron D. and R. Myerson (1982). "Regulating A Monopolist With Unknown Cost" Econometrica 50, 911930

[3] Chang, R. (1998) “Credible Monetary Policy in an Infinite Horizon Model: Recursive Approaches," Journal of Economic Theory, 81: 431-461.

[4] CBN Statistical Bulletin $2013 \quad$ Fourth Quarter Available at http://www.cenbank.org/documents/annualreports.asp Accessed on $29^{\text {th }}$ April 2014

[5] Harsanyi, John C. 1967/1968.Games with Incomplete Information Played by "Bayesian" Players, I-III. Management Science 14.3:159-82, 14.5:320-34, 14.7:486-502.

[6] Hurwicz, Leonid. 1960. Optimality and Informational Efficiency in Resource Allocation Processes.In Mathematical Methods in the Social Sciences, 1959, edited by Kenneth J. Arrow, Samuel Karlin, and Patrick Suppes. Stanford: Stanford University Press. 1973. The Design of Mechanisms for Resource Allocation. American Economic Review 63.2:1-30.

[7] Hurwicz, Leonid, and Stanley Reiter. 2006. Designing Economic Mechanisms. New York: Cambridge University Press.

[8] Hart O. and B. Holmstrom (1987) "Theory of Contracts" working paper department of economics. March 1986 Massachusetts Institute of Technology (MIT), Department of Economics

[9] J.J. Laffont and J. Tirole, A (1993) Theory of incentives in regulation and procurement MIT Press Lewis T. and D Sappington (1988) "Regulating A Monopolist with Unknown Demand" American Economic Review. 78, 986-998

[10] Loeb, M. and W.A.Magat (1979), A decentralized method for utility regulation, Journal of Law and Economics 22, $399-404$.

Mathios, Alan D., and Robert P. Rogers (1989), "The Impact of Alternative Forms of State Regulation of AT\&T on Direct-dial, Long-distance Telephone Rates," Rand Journal of Economics 20:437-453

[11] Maskin E.(2008) Mechanism Design: How to Implement Social Goals. Les Prix Nobel 2007 Reprinted in American Economic Review, 98 (3), 2008, pp. 567-76. Also reprinted in Russian, Proceedings of the Tenth Annual Conference on Economics, Moscow, 2009 
[12] Maskin E, Dasgupta P.(2007) Bargaining and Destructive Power. Annals of Economics and Finance. 2007;8(2):217-227. Available at http://scholar.harvard.edu/maskin/publicationsAccessed on $29^{\text {th }}$ April 2014

[13] Maskin E, Tirole J.(2008) "Public-Private Partnerships and Government Spending Limits." International Journal of Industrial Organization. 2008;26(2):412-420 Available at http://scholar.harvard.edu/maskin/publicationsAccessed on $29^{\text {th }}$ April 2014.

[14] Obasi, N. K. (2003). Foreign Participation in the Nigerian Oil and Gas Industry Available at http://www.onlinenigeria.com/links/adv.asp?blurb=493 Accessed on 19th March 2014

[15] Ojeaga P (2017). "Repeatable Scalable Business Models" Can Innovation Drive An Entrepreneurs Unvalidated Business Model". European Journal of Business and Innovation Research, European Centre for Research Training and Development UK. Vol. 5 No. 5 pp 1-12 December 2017.

[16] Ojeaga P. (2015) "Can Africa's Young Drive Innovation? Investigating the Effect of Entrepreneurial Innovation on Economic Growth in Africa." Journal of Applied Quantitative Methods, Publication of Association for Development through Science and Education, Romania (ADSE)Vol.10 No.4 pp.15-26.

[17] Available at http://www.jaqm.ro/issues/volume-10,issue-4/pdfs/jaqm_vol10_issue4.pdf

[18] Alege P., George E., Ojeaga P. and Oluwatimiro Q. (2015) "Is Africa's Current Growth Reducing Inequality? Evidence from Some Selected African Countries" Computational Methods in Social Sciences. Journal of Nicolae Titulescu University of Bucharest Romania Vol. III Issue I 2015 Available at http://cmss.univnt.ro/wp-content/uploads/vol/split/vol_III_issue_1/CMSS_vol_III_issue_1_art.005.pdf

[19] Ojeaga, P.(2014)."Foreign Aid and African Exporters: Help or Harm? Vol.4, No.12, 2014. United States IISTE Journal of Developing Country Studies,EBSCO Indexed, Impact Factor $=5.05$, available at http://www.iiste.org/Journals/index.php/DCS/article/view/13493/13813.

[20] Ojeaga, P. and Odejimi, D. (2013). "Does Bank Lending Incite Growth? The Impact of Commercial Lending On Real Sector Growth in Nigeria?” Ekonomika Management Inovace Journal Olomouc Czech Republic. Vol. 5 issue 7 March Google Scholar and SCIRUS Indexed, available at http://emi.mvso.cz/2013_03.htm.

[21] Olurinola, I., Alege, P.O., Ojeaga, P. andOluwatimiro, Q. (2014). A Practical Review of Mechanism Design: How Implementable is It Within The Nigerian Context? Investigating the Role of PPP On Social Outcomes in Nigeria". Journal of Knowledge Management, Economics and Information Technology Vol. IV, Issue 3 June 2014. Index Copernicus.

[22] Reiter, Stanley.(2003.) Preface to "Interdependent Preferences and Groups of Agents."In Chopra et al. 2003.

[23] Sappington D. (1982). "Optimal Regulation of Research and Development Under Imperfect Information," The Bell Journal of Economics, Vol. 13(2), Autumn 1982, pp. 354-368.

[24] Tsai Y (2007) "Emergence of rating agencies: Implications for establishing a regional rating agency in Asia" ADBI working paper series, No. 241 available at http://www.econstor.eu/bitstream/10419/53646/1/640576842.pdf Accessed on 19th March 2014

[25] UN Report 2011, “The Millennium Development Goals Report" Available at http://www.un.org/millenniumgoals/pdf/(2011_E)\%20MDG\%20Report\%202011_Book\%20LR.pdf Accessed on $29^{\text {th }}$ April 2014

[26] World Bank Statistics (2010) Available at http://data.worldbank.org/data-catalog/world-developmentindicators/wdi-2010. Accessed on 19th March 2014. 